\title{
BRITISH GLACIOLOGICAL SOCIETY
}

The "Association for the Study of Snow and Ice", founded in 1936, has changed its title and is now known as the "British Glaciological Society". The President of the Society is Mr Gerald Seligman, and the Vice-President is Mr J. M. Wordie. The Society is open to all who have scientific, practical or general interest in any aspect of snow and ice study. Membership is by nomination. Meetings for the purpose of reading and discussing papers are held at about three-monthly intervals, in London, Cambridge or elsewhere. By permission of the President and Council, the temporary headquarters are at the Royal Geographical. Society, Kensington Gore, London, S.W. 7.

\section{INTERNATIONAL COMMISSION OF SNOW AND GLACIERS}

[For a previous note on this subject see The Polar Record, No. 22, July 1941, pp. 451-53.] The following subjects were selected at Washington in 1939 for papers to be read at Oslo in 1947 before the International Commission of Snow and Glaciers, one of the Commissions of the International Association of Hydrology. The Association is one of the component bodies of the International Union of Geodesy and Geophysics, which is sponsoring the meeting at Oslo:

(1) The origin, drift and ablation of icebergs as aids in forecasting their seasonal appearance.

(2) The physical changes in the snow conducive to run-off and particularly to flooding.

(3) The study of the crystal structure of a glacier and its influence upon glacier movement.

Mr G. Seligman, who has been appointed Chairman of the British Group of the Commission of Snow and Glaciers, will be glad to hear from anyone who wishes to make a contribution to these subjects by writing a paper or by taking part in the discussions $\mathrm{He}$ will be pleased to answer any inquiries addressed to him c/o Royal Geographical Society, Kensington Gore, London, S W. 7.

\section{OBRUCHEV INSTITUTE FOR THE STUDY OF PERMANENTLY FROZEN SOILS}

[Summarised from an article by A. I. Dementiev and V. F. Tumel, "Civil Engineering in Frozen Soil, U.S.S.R.", Canadian Geographical Journal, Vol. 32, No. 1, 1946, pp. 32-33.]

Approximately $47 \%$ of the total area of the U.S.S.R. lies within a region where the soil is permanently frozen and every year industrial organisations are moving into this region. The civil engineering problems peculiar to frozen soil are therefore of importance to the economic development of the country, and many of these are being tackled by the Obruchev Institute for the Study of 